\title{
Sociale media als meetinstrument
}

\author{
AUTEUR Koen Tieskens
}

Vermoedelijk ligt er in de la van elke geografie- of planologiedocent wel een stapel scripties over gentrification te verstoffen. Het proces, waarin een verpauperde buurt wordt gekoloniseerd door hippe figuren, en vervolgens populair wordt onder de middenklasse waardoor huizenprijzen de lucht in schieten is uit-en-te-na beschreven. Bekende voorbeelden zijn de Jordaan in Amsterdam, Lombok in Utrecht en Greenwich Village in New York. Jeroen Beekmans werpt echter een interessant nieuw licht op gentrification door het te meten via social media-activiteit.

Voor zijn analyse maakt Beekmans gebruik van Foursquare, een mobiele app die gebruikers hun geografische locatie laat delen met hun vrienden. Het profiel van de stedelijke pioniers die gentrifcation in gang zetten, lijkt namelijk erg op het profiel van de Foursquaregebruiker. Daarom wil Beekmans aantonen dat een hoge mate van Foursquare activiteit zou kunnen duiden op beginnende gentrification.

De originele invalshoek van Beekmans lijkt voort te komen uit persoonlijke ervaringen. In een screenshot van zijn eigen mobiele telefoon blijkt hij 1071(!) keer zijn locatie te hebben gedeeld met zijn vrienden. Toch slaagt hij erin voldoende afstand van zijn onderwerp te behouden, waardoor de lezer niet alleen meer te weten komt over Foursquare, maar ook over gentrification. Beekmans onderzoekt Foursquare-activiteit in Amsterdam-Noord. Van dit gebied is bekend dat in verschillende buurten verschillende

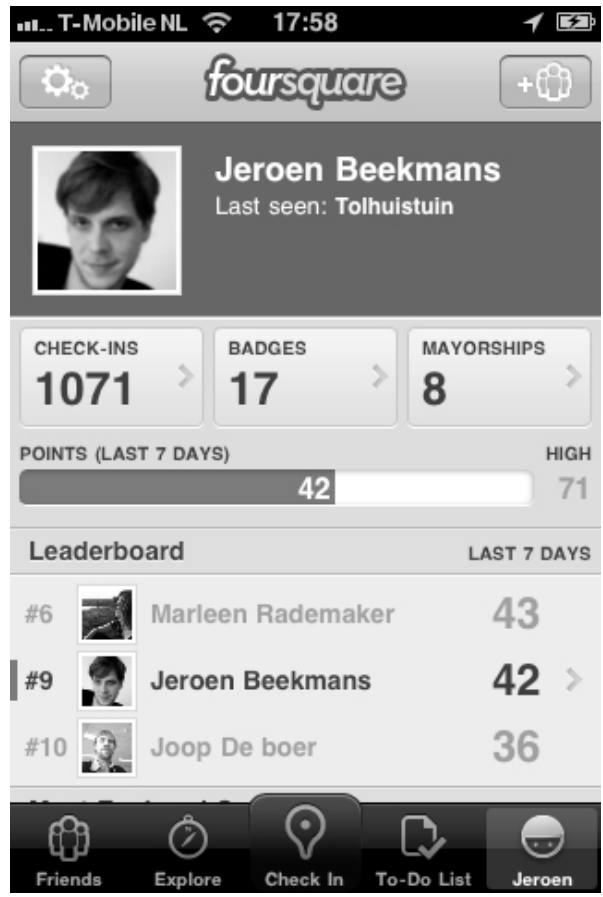

fases van gentrification aan de gang zijn. Zo wil hij testen of hij met Foursquare daadwerkelijk gentrification kan aantonen. De Foursquare-activiteit blijkt het grootst te zijn in de gebieden rond de NDSM-werf, Buiksloterham, Nieuwendammerdijk en in mindere mate in Oud-Noord. Omdat dit juist de gebieden zijn waar ook door andere onderzoeken beginnende gentrification is geconstateerd, concludeert Beekmans dat hij door het Foursquare gebruik te meten gentrification kan aantonen. Het is jammer dat hij Amsterdam-Noord niet heeft vergeleken met een volledig niet-gentrificerend gebied. Interessanter is echter dat Beekmans' methode het gedrag van gentrifiers onderzoekt in plaats van hun woonsituatie. Foursquare geeft inzicht in de werk- en vrijetijdsbesteding van hippe jonge mensen die met hun gedrag gentrification in gang kunnen zetten zonder zelf te wonen in het gebied. Volgens Beekmans heeft de literatuur zich te veel gericht op residentieel gebaseerde gentrification terwijl in een nieuwe benadering "de aanwezigheid van relevante culturele gelegenheden en horeca, inclusief de cultural industries [kan fungeren] als een startpunt voor gentrification". Gentrification wordt volgens Beekmans in gang zet door mensen die in een gebied komen, niet door de mensen die er wonen. Zijn bewering dat de literatuur zich vooral gericht heeft op residentiële gentrification is echter overdreven. Zelfs voordat de term gentrification überhaupt geïntroduceerd werd, stond bijvoorbeeld Jane Jacobs al uitgebreid stil bij de rol van culturele gelegenheden en horeca in deze context. Dat neemt niet weg dat Foursquare erg bruikbaar kan zijn in het in kaart brengen van de rol van de nietresidentiële gentrifiers

Het combineren van social media met gentrification werpt een aantal interessante vragen op. Zo bespreekt Beekmans zelf uitgebreid de houdbaarheid van Foursquare in het bijzonder als indicator van gentrification. Aan de Nederlandse netwerksite Hyves zien we dat wat vandaag hip en happening is, morgen zo weer oubollig en mainstream kan zijn. Het gebruik van social media als meetinstrument in het algemeen doet nog een andere vraag rijzen: in hoeverre is wat mensen op social media met anderen delen, een weergave van hun werkelijke gedrag? En als dat niet zo is, is dat dan problematisch voor het gebruiken van social media als gentrificationindicator, of juist niet? Stof genoeg om de scriptie-la voor gentrification nog maar niet bij het oud papier te zetten.

Beekmans, Jeroen (2011) Check-In Urbanism: exploring gentrification through Foursquare activity. Masterscriptie Human Geography UvA. http://dare.uva.nl/scriptie/391330 